УДК 330.322:656.2

\title{
УПРАВЛІННЯ РЕАЛІЗАЦІЕЮ СПІЛЬНИХ ІНВЕСТИЦІЙНИХ ПРОЕКТІВ ЗА УЧАСТЮ ПІДПРИЕМСТВ ЗАЛІЗНИЧНОГО ТРАНСПОРТУ В УМОВАХ ЦИФРОВІЗАЦІЇ
}

\author{
Дикань В.Л., д.е.н., професор, \\ Обруч Г.В., к.е.н., докторант (УкрДУЗТ)
}

\begin{abstract}
У статті доведена необхідність перегляду існуючої наразі системи управління реалізацією інвестиційними проектами підприємствами залізничного транспорту в умовах формування цифрової економіки. Обтрунтована економічна та стратегічна доиільність реалізаиіі спільних інвестииійних проектів за участю залізничних підприємств. 3'ясовано, що наразі істотно зросла кількість досліджень, що стосуються проблем асиметрії інформації у сфері інвестиційної діяльності. Доведена необхідність використання конщепщії проактивного управління, як ключового елементу зниження проблем асиметрії інформаиії та подолання інших ризиків під час управління реалізацією спільними інвестиційними проектами та забезпечення гармонійного розвитку підприсмств залізничного транспорту. Запропоновано модель управління реалізацією спільних інвестиційних проектів підприємствами залізничного транспорту, яка якісно вирішує проблеми забезпечення ефективності реалізації спільних інвестиційних проектів шляхом формування та реалізації попереджуючих управлінських дій, які враховують можливість виникнення негативних результатів від реалізації спільних інвестиџійних проектів.
\end{abstract}

Ключові слова: управління, проактивне управління, спільний інвестиційний проект, інвестиційна діяльність, підприємства залізничного транспорту, цифровізація.

\section{УПРАВЛЕНИЕ РЕАЛИЗАЦИЕЙ СОВМЕСТНЫХ ИНВЕСТИЦИОННЫХ ПРОЕКТОВ С УЧАСТИЕМ ПРЕДПРИЯТИЙ ЖЕЛЕЗНОДОРОЖНОГО ТРАНСПОРТА В УСЛОВИЯХ ЦИФРОВИЗАЦИИ}

\author{
Дикань В.Л., о.э.н., профессор, \\ Обруч А.В., к.э.н., докторант (УкрГУЖТ)
}

В статье доказана необходимость пересмотра существующей сейчас системь управления реализаџией инвестиционных проектов предприятиями железнодорожного транспорта в условиях формирования ичифровой экономики. Обоснованна экономическая и стратегическая иелесообразность реализачии совместных инвестиционных проектов при участии железнодорожных предприятий. Выяснено, что сейчас существенно возросло количество исследований, касающихся проблем асимметрии информации в сфере инвестиционной деятельности. Доказана необходимость использования концепции проактивного управления, как ключевого элемента снижение проблем асимметрии информачии и преодоления других рисков при управлении реализацией совместными инвестиционными проектами и обеспечения гармоничного развития предприятий железнодорожного транспорта. Предложена

(C) Дикань В.Л., Обруч Г.В.

Вісник економіки транспорту і промисловості № 69, 2020 
модель управления реализацией совместными инвестиционными проектами предприятияли железнодорожного транспорта, которая качественно решает проблемы обеспечения эффективности реализации совместных инвестиционных проектов путем формирования и реализации предупреждающих управленческих действий, которые учитывают возможность возникновения негативных результатов от реализачии совместных инвестиционных проектов.

Ключевые слова: управление, проактивное управление, совместный инвестиционный проект, инвестиционная деятельность, предприятия жслезнодорожного транспорта, цифровизация.

\title{
MANAGEMENT OF THE IMPLEMENTATION OF A JOINT INVESTMENT PROJECT WITH THE PARTICIPATION OF RAILWAY ENTERPRISES IN DIGITAL CONDITIONS
}

\author{
Dykan V. L., doctor of Economics, professor, \\ Obruch H.V., candidate of Economics, doctoral student (USURT)
}

The article proves the need to revise the current system of managing the investment project implementation by railway companies in the conditions of digital economy formation in Ukraine and in the world. The economic and strategic feasibility of joint investment projects and the involvement of railway enterprises are substantiated. It is proved that a joint investment project that brings together several railway undertakings during its implementation is the main condition for ensuring their competitiveness in the domestic and international market of transport and logistics services. It has been found that the number of studies concerning problems of information asymmetry in the sphere of investment activity has increased significantly in the world economic literature. The necessity of using the concept of proactive management as a key element of reducing the problems of information asymmetry and overcoming other risks in managing the implementation of joint investment projects of railway undertakings in the context of digitalization has been proved. The study of fundamental scientific achievements in the field of information asymmetry, risk management, as well as investment management in the management of railway transport enterprises confirms the need for the introduction and further improvement of modern digital technologies to reduce information asymmetry between the entities of investment activities during the implementation of joint venture rail transport. In addition, one can conclude that state regulatory measures can improve the situation in the market of transport and logistics services in the conditions of digital economy in the world. In general, the importance of this scientific research lies in the development of a model for managing the implementation of joint investment projects by railway undertakings through the lens of proactive management, which underlies digitalization technology. This generally provides a new understanding of the problems of ensuring the effectiveness of joint investment projects through the formation and implementation of preventative management actions that take into account the possibility of negative results from the implementation of joint investment projects.

Key words: management, proactive management, joint investment project, investment activity, railway undertakings, digitization.

Постановка проблеми. В останні десятиліття ринок транспортнологістичних послуг трансформувався, з'явилося безліч суб'єктів господарювання

(приватні оператори вантажних та пасажирських перевезень, приватні оператори локомотивної тяги, транспортно-логістичні центри та ін.) та, 
відповідно, виникли нові, не характерні до теперішнього часу типи взаємодії, що стало загрозою для забезпечення збалансованого розвитку підприємств залізничного транспорту. Зміни відбуваються не лише в межах внутрішнього ринку, трансформація спостерігаються й у макрооточенні (глобалізація, цифровізація, інтелектуалізація та ін.), що в свою чергу обумовлює

конкурентоспроможності залежність підприємств від наявності ефективно сформованих інвестиційних проектів відповідно до умов сьогодення. Перш за все мова йде про управлінську та організаційну складові інвестиційного процесу, що дозволить зробити його мінімально ризиковим та максимально ефективним, а це, в свою чергу, сприятиме залученню вітчизняних $\mathrm{i}$ закордонних інвесторів та стане основою для технікотехнологічного оновлення підприємств залізничного транспорту.

Згідно 3 даними досліджень українських та зарубіжних авторів [4, 5, 7], одним 3 найбільш істотних економічних чинників, що впливають на інвестиційну діяльність підприємств залізничного транспорту України в умовах світової цифровізації та інтелектуалізації, $\epsilon$ інформація. За відсутності достовірної та актуальної інформації про інвестиційні проекти підприємств залізничного транспорту, їх поточний стан, пропозиції інвесторів та ін., АТ «Укрзалізниця» буде приречена на банкрутство, адже наразі більшість інвестиційних рішень щодо оновлення процесу експлуатації $\epsilon$ взаємообумовленими та вимагають від підприємств залізничного транспорту переважно спільного рішення. Тобто ефективна та максимально адаптована до умов господарювання організація спільних інвестиційних проектів $\epsilon$ запорукою збалансованого розвитку підприємств залізничного транспорту.

Аналіз останніх досліджень $i$ публікацій та виділення невирішених частин загальної проблеми. Проблемам розвитку підприємств залізничного транспорту та аспектам їх інвестиційної діяльності присвячено багато робіт зарубіжних і вітчизняних авторів, зокрема Альошиної I. А., Геращенкової Т. М., Дикань В. Л., Островерх Г. Є., Соломнікова I.В., Слагіна Ю. В., Глущенко Ю. В., Цапко Л. В., Корінь М.В., Кондратюка М.В., Обруч Г.В., Полякової О. М., Шраменко О.В. та інших [1-6]. Особливості формування цифрової економіки та iї вплив на ефективність господарювання підприємств залізничного транспорту розглядаються в наукових працях Овчиннікової В.О., Торопової В.І., Покусаєва О.М., Климова А. А., Куприяновського В. П., Морхата П. М., Наміота Д. Є., Токмакової I.В., Чередниченка О.Ю., Войтова I.M., Паламарчук Я.С. [7-9] та інших. Актуальність дослідження обумовлена відсутністю теоретичних та методичних напрацюванню щодо формування дієвої моделі управління реалізацією інвестиційних проектів підприємств залізничного транспорту в сучасних умовах господарювання.

Тому, метою статті є опрацювання концептуальних положень управління реалізацією спільних інвестиційних проектів за участю підприємств залізничного транспорту в умовах цифровізації.

Виклад основного матеріалу. Катастрофічна зношеність локомотивів, вантажних та пасажирських вагонів, моторвагонного рухомого складу, спеціалізованої техніки щодо ремонту i поточного утримання залізничної колії та інших основних фондів обумовлюють необхідність негайного пошуку дієвих механізмів, що забезпечать активізацію інвестиційної діяльності підприємств залізничного транспорту та їх ефективність. Для того, щоб окреслити зазначене детально розглянемо всі аспекти інвестиційної діяльності залізничних підприємств та зупинимося на найбільш 
важливих, які $\epsilon$ ключовими в процесі забезпечення їх збалансованого розвитку.

Спочатку слід обов'язково

наголосити, що наразі активізація інвестиційної діяльності підприємств залізничного транспорту переважно можлива у стратегічній єдності залізничних підприємств під час реалізації інвестиційних проектів. Пов'язано це із лібералізацією ринку залізничних перевезень i можливістю забезпечення експлуатаційної діяльності та процесу залізничних перевезень різними підприємствами (АТ «Укрзалізниця», приватні оператори вантажних та пасажирських перевезень, приватні оператори локомотивної тяги та ін.), які наразі стають активними гравцями на ринку (рис. 1).
Так, наприклад, інноваційне оновлення залізничної колії, що знаходиться на балансі АТ «Укрзалізниця», відповідно до умов цифровізації залізничної галузі, потребує придбання та введення в експлуатацію нових технічних засобів та приладів діагностування стану колії. Проте придбання приватним оператором локомотивної тяги тягового рухомого складу, що матиме на борту обладнання для виконання дефектоскопіювання колії, зніме необхідність АТ «Укрзалізниця» у придбанні та введенні вищезазначеного обладнання і дозволить всім учасникам даного інвестиційного проекту отримати додатковий економічний ефект.

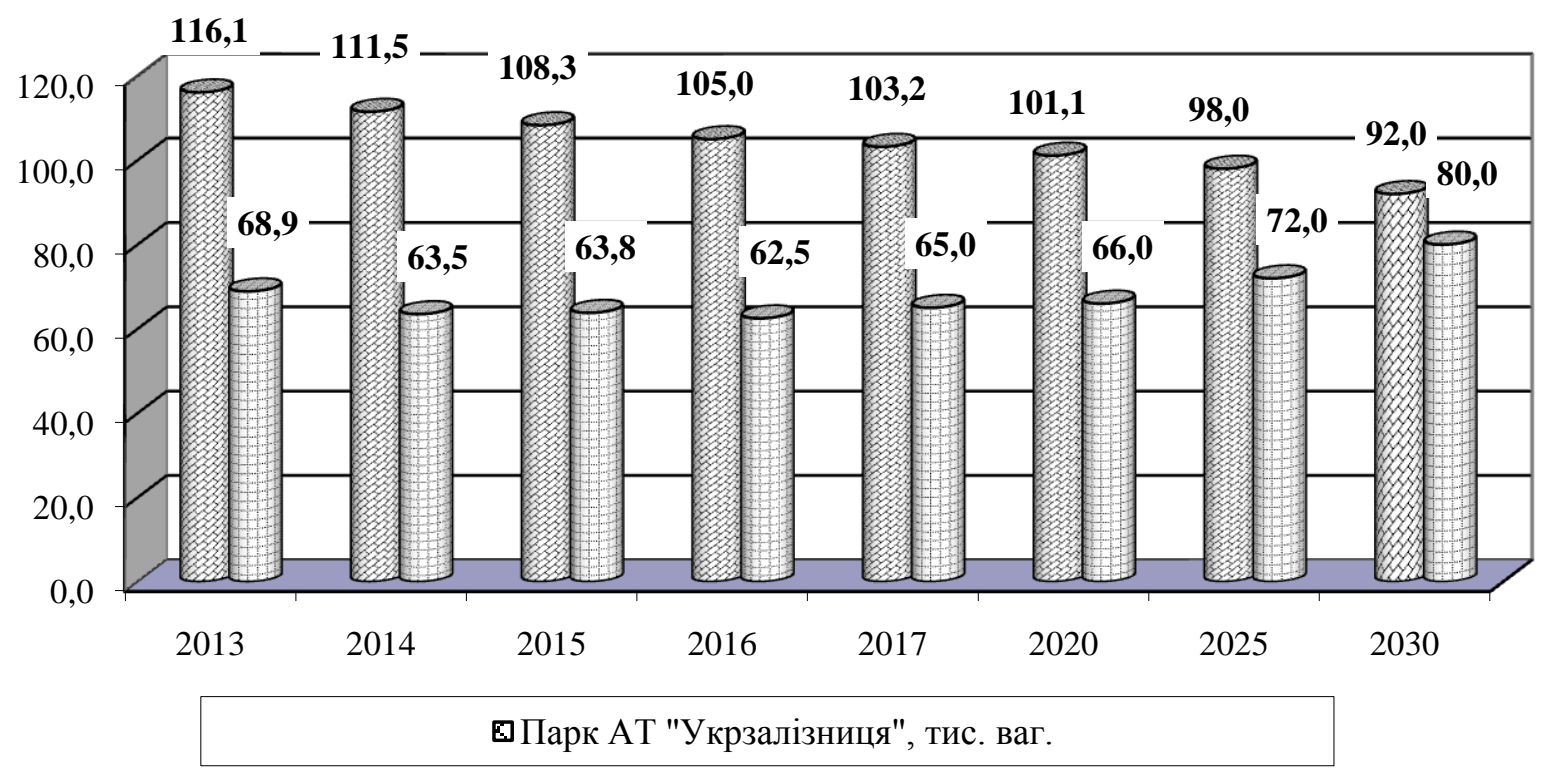

Рис. 1. Співвідношення парків АT «Укрзалізниця» і приватних компаній до 2030 року за очінкою UIF [10]

В таких умовах спільний даного виду інвестиційних проектів в інвестиційний проект, що поєднує умовах становлення цифрової економіки. декілька підприємств залізничного Враховуючи багатосуб' єктність транспорту під час його реалізації, $\epsilon$ інвестиційного процесу підприємств головною умовою забезпечення їх залізничного транспорту необхідно конкурентоспроможності на вітчизняному обов'язково звернути увагу на те, що під та міжнародному ринку транспортно- час їх ділової взаємодії повсякчасно логістичних послуг. Зважаючи на виникають асиметрії інформації, які зазначене сконцентруємо увагу на мають негативний вплив на особливостях формування та реалізації результативність функціонування 
інвестиційної

платформи

«Укрзалізниця» та, відповідно, самого інвестиційного процесу.

Спочатку з'ясуємо сутність поняття «асиметрія інформації». 3 економічної точки зору - це ситуація, коли деякі економічні суб'єкти володіють більш повною i правдоподібною інформацією, тоді як інші суб'єкти, які беруть участь в угоді, не володіють нею. Зокрема, наприклад, більш обізнаними виявляються ті суб'єкти інвестиційної діяльності, які володіють внутрішньою інформацією, за родом діяльності недоступною їх контрагентам [11]. Крім того, зміст даного поняття можна доповнити розглядаючи дослідження в галузі економічної теорії інформації, нової інституціональної економічної теорії, концептуальних положень ризик-менеджменту та ін. [1218].

Асиметрія інформації виникає 3 невизначеності функціонування економічних суб'єктів господарювання. Таким чином, щоб знищити асиметрію інформації, необхідно виключити 3 дійсності всю невизначеність, а це буде неможливо, тому знизити іiї ступінь можна тільки за допомогою грамотного i тактичного поширення інформації, а також iii сприйняття. Отже ефективність управління інвестиційною діяльністю залежить від зниження ступеня інформаційного ризику.

Шульц Д.Н. в своїй роботі встановив, що при існуванні асиметричної інформації з'являється сприятливе середовище для створення монополій i зростання фінансово-економічного стану одних суб' єктів інвестиційної діяльності на шкоду іншим (виникає ризик з боку бізнеспартнера) [14]. Це відбувається через існування можливості отримання надприбутку при використанні «стейкхолдерської» інформації. Подібна ситуація не виникає лише в тому випадку, якщо витрати пошуку такої інформації вкрай високі.
Дослідження вищезазначених робіт в сукупності дозволило дійти висновку, що асиметрія інформації $\epsilon$ причиною виникнення великої кількості ризиків для господарювання сучасних підприємств, а тому фінансово-економічний стан підприємств залізничного транспорту в умовах становлення неоіндустріальної економіки покращується прямо пропорційно збільшенню доступності та правдоподібності наявної інформації. Слід зазначити, що наслідками асиметрії інформації в умовах формування та реалізації спільних інвестиційних проектів можуть вважатися окремі випадки двох класичних для світової економічної літератури ситуацій: несприятливий відбір бізнес-партнерів і ризик негативної дії 3 боку бізнес-партнера.

Проблема ризику негативної дії 3 боку бізнес-партнера завжди існує в тому випадку, коли неможливо дізнатися, які дії чинить одна зі сторін бізнес-угоди [18]. Дослідники проблеми негативної дії з боку бізнес-партнера [19] розглядають декілька ключових причин іiі виникнення:

по-перше, це непоєднаність інтересів бізнес-партнерів (необхідно щоб інтереси збігалися, i можливо було б прийти до компромісу та, відповідно, встановити чіткі межі відповідальності);

по-друге, однією 3 найважливіших причин $\epsilon$ наявність складнощів при контролі виконання умов угоди, що пов'язана зі спільною реалізацією інвестиційного проекту, або наявність надзвичайно високих витрати як результат проведення контролю.

Проблема негативної дії з боку бізнес-партнера полягає також в неблагонадійності партнерів, які отримують інформацію для оформлення документів пов'язаних із реалізацією спільного інвестиційного рішення і згодом не дотримуються вимоги щодо умов їх виконання. В рамках боротьби 3 даною проблемою можна зазначити, що доцільно здійснити ряд регулюючих заходів, щодо зберігання, обліку і надання інформації 
іншим бізнес-партнерам в електронних журналах, тобто забезпечити поступовий перехід до реалізації спільних інвестиційних проектів на основі відповідної цифрової платформи. Цей захід дозволить істотно збільшити прозорість, знизити ступінь ризику та витрати інвесторів, а також підприємств залізничного транспорту, що будуть реалізовувати спільне інвестиційне рішення.

Для того, щоб знизити інформаційні асиметрії слід передбачити базові правила поведінки суб'єктів господарювання при укладанні договорів інвестування та реалізації спільних інвестиційних рішень. Надалі це дозволить істотно скоротити витрати, пов'язані 3 оформленням i виконанням зазначених договорів.

Доцільно також розглянути проблему несприятливого відбору бізнеспартнерів для спільної реалізації інвестиційного рішення, за якої суб'єкти інвестиційної діяльності можуть не надавати необхідних відомостей або надавати неправдиві відомості.

На нашу думку, для визначення бізнес-партнерів для спільної реалізації інвестиційних проектів слід використовувати методику, яка в якості пріоритету ділової співпраці матиме: максимізацію синергетичного ефекту, зростання якісних показників експлуатаційної діяльності, забезпечення досягнення стратегічних цілей, мінімізацію ступеню ризику.

Вирішенню проблеми взаємодії бізнес-партнерів в аспекті досліджуваного питання сприяє процес електронного документообігу, а точніше формування цифрової платформи взаємодії підприємств залізничного транспорту в межах реалізації спільних інвестиційних проектів.

3 точки зору цифрових нововведень можна відзначити, що на поточний момент можна використовувати також наявну базу комп'ютерних програм, так, наприклад, всі угоди можуть формуватися через програму
В2В («бизнес - бизнесу»). Програма В2В повнофункціональний додаток для розрахунку i оформлення договорів між бізнес-партнерами. Це дозволить максимально збільшити прозорість i доступність інформації всім економічним суб'єктам інвестиційної діяльності. Список можливостей системи i доступних комп'ютерних програм постійно розширюється.

Доцільним є також використання системи онлайн-андеррайтингу, що дозволить забезпечити високу якість проведення процедури узгодження i фіксації рішень, які можна застосувати далі в бізнес-процесах під час реалізації спільних інвестиційних рішень. Ця система необхідна особливо в тих випадках, коли неможливо розрахувати i оформити відповідні договори у стандартному порядку.

Зважаючи на необхідність своєчасності виявлення ризиків, які мають негативну тенденцію в умовах цифровізації, та розробки системи попереджуючих управлінських дій, доцільним $€$ введення в практику інвестиційної діяльності передінвестиційної і економічної діагностики підприємств залізничного транспорту, що бажають стати бізнеспартнерами.

Даний етап слід виконувати за допомогою цифрових додатків. Це дозволить знизити ймовірність шахрайських дій 3 боку суб'єктів інвестиційної діяльності, оскільки всі дані про результати відразу відправляються до загальної електронної бази.

3 цією метою пропонуємо до ключових етапів інвестиційного процесу (передінвестиційний, інвестиційний, експлуатаційний), що наразі існують в економічній теорії, обов'язково додати погоджувальний етап, що буде вирішувати завдання: перевірка, уточнення та узгодження ключових ідеї реалізації спільного інвестиційного проекту; ідентифікація, діагностика та затвердження 
головних учасників спільного інвестиційного проекту; встановлення та оцінка інвестиційних ризиків, визначення напрямків щодо їх подолання; загальне моделювання та проектування спільного інвестиційного проекту; прийняття попереднього рішення щодо доцільності реалізації спільного інвестиційного проекту, укладання контракту та ін.

Даний етап доцільно виконувати на базі цифрової інвестиційної платформи підприємств залізничного транспорту.

Зважаючи на структурну складність реалізації спільного інвестиційного рішення, а також відповідну складність прийняття комплексних рішень i вибору сценаріїв поведінки суб'єктів інвестиційної діяльності вважаємо, що управлінські функції слід делегувати Центру управління реалізацією спільних інвестиційних проектів на підприємствах залізничного транспорту. Головною метою даного центру повинно стати формування дієвих рішень спрямованих на забезпечення ефективності реалізації спільних інвестиційних проектів підприємствами залізничного транспорту, що грунтуються на попереджуючих управлінських діях, які враховують можливість виникнення негативних результатів від реалізації спільних інвестиційних проектів. Крім того в структурі Центру слід окремо виділити департамент інформаційної безпеки, який буде координувати i контролювати розподіл ролей посадових осіб, що будуть відповідальними за операції відповідно до договорів інвестування.

Отже, зважаючи на все вищезазначене виділимо основні аспекти реалізації підприємствами залізничного транспорту спільних інвестиційних рішень: структурна складність; складність функціонування; складність прийняття рішень i вибору сценаріїв поведінки; складність ї формального опису i моделювання та ін.

У цих умовах, враховуючи формування цифрової економіки в державі, для забезпечення необхідного ступеня автономності, якості та оперативності управління складними об'єктами (яким $є$ спільний інвестиційний проект, що реалізують декілька підприємств залізничного транспорту) необхідно, поряд iз попередньо вказаними засобами, приділити увагу:

забезпеченню модельноалгоритмічному опису процесів смислової інтерпретації всіх можливих і неможливих ситуацій, що можуть виникнути під час реалізації спільних інвестиційних проектів;

- вирішенню всього переліку завдань комплексної автоматизації та інтелектуалізації процесів управління реалізацією спільними інвестиційними проектами в різних умовах.

Однак, на жаль, в переважній більшості випадків на практиці процеси моніторингу та управління реалізацією спільних інвестиційних проектів у зазначеному вище трактуванні автоматизовані лише частково. Як правило, в сучасних автоматизованих системах управління керівникам надається смислова інформація тільки про стан їх елементів, а не об'єктів контролю в цілому. Зазначені обставини призводять до того, що інтегральна оцінка стану реалізації спільних інвестиційних проектів, як i формування необхідних управляючих впливів, здійснюється керівниками в основному грунтуючись на індивідуальній експертній думці.

Стосовно процесів моніторингу та управління реалізація властивості живучості передбачає оперативне формування таких процедур збору, обробки та аналізу даних, а також відповідного обчислювального середовища, при якому виявлення, локалізація і ліквідація збоїв i відмов елементів та підсистем спільного інвестиційного проекту буде відбуватися значно раніше, ніж виявляться можливі наслідки зазначених збоїв. В цьому i полягає основний зміст розглянутих завдань синтезу технологій проактивного (попереджувального) моніторингу та 
управління, які наразі слід розглядати як перспективні технології управління реалізацією спільним інвестиційним проектом підприємствами залізничного транспорту (complexity management).

Слід зазначити, що процеси проактивного управління реалізацією спільного інвестиційного проекту за участю підприємств залізничного транспорту характеризуються додатковими особливостями в сучасних умовах господарювання, коли постійно відчувається дефіцит ресурсів (викликаний різними причинами суб'єктивного i об'єктивного характеру) і стає неможливим підтримувати необхідний рівень ефективності інвестиційної діяльності. У даних ситуаціях проактивне управління реалізацією спільного інвестиційного проекту за участю підприємств залізничного транспорту повинно супроводжуватися цілеспрямованими процедурами реконфігурації структур як самого інвестиційного проекту, так i процесу реалізації для забезпечення максимального рівня їх ефективності.

Проактивне управління реалізацією спільного інвестиційного проекту за участю підприємств залізничного транспорту, на відміну від традиційно використовуваного на практиці реактивного управління (яке орієнтоване на оперативне реагування на інциденти i подальше їх недопущення), передбачає запобігання виникненню ризиків за рахунок створення у відповідній системі моніторингу та управління принципово нових попереджувальних можливостей при формуванні керуючих впливів на основі реалізації концепції системного (комплексного) моделювання. В таких умовах стає можливим вирішення задач, що $є$ негайними наразі для забезпечення ефективності управління спільними інвестиційними проектами, i виконання яких до цього було нереальним:

- оперативне коригування способів $\mathrm{i}$ цілей управління реалізацією спільними інвестиційними підприємствами залізничного транспорту, зміна послідовності виконання етапів інвестиційної діяльності відповідно до змін макро- та мікро- умов;

- переміщення в просторі окремих елементів і підсистем системи управління реалізацією спільними інвестиційними рішеннями підприємствами залізничного транспорту;

- перерозподіл і децентралізація функцій, завдань, алгоритмів управління та інформаційних потоків між суб'єктами спільної інвестиційної діяльності;

- використання гнучких технологій управління реалізацією спільними інвестиційними рішеннями підприємствами залізничного транспорту та ін.

У роботах $[12,14,15,16,19]$ перераховані напрями реалізації принципу необхідної різноманітності отримали свою подальшу конкретизацію i розвиток для ряду предметних областей. Авторами цих робіт підкреслюється особлива актуальність створення методологічних i методичних основ вирішення проблем керованої самоорганізації, як найбільш ефективного способу боротьби 3 різноманітністю станів зовнішнього середовища. При цьому технологія керованої самоорганізації передбачає реалізацію цілеспрямованих процесів підтримки динамічної відповідності структур і функцій у відповідних складних організаційно-технічних і соціальноекономічних системах.

Аналіз сучасних тенденцій розвитку інформаційних технологій i систем свідчить, що всі провідні зарубіжні та вітчизняні компанії, які спеціалізуються в даній області, будували і будують корпоративні інформаційні інфраструктури тільки за вертикальним принципом, керуючись приватними критеріями i погано погоджуючи власні подання 3 вимогами бізнесу [16]. В результаті традиційні підходи до автоматизації бізнеспроцесів знаходяться в даний час якщо не в кризовому, то в передкризовому стані. А 
тому труднощі управління реалізацією спільними інвестиційними проектами виходять за рамки адміністрування окремими програмними середовищами.

Необхідність інтеграції декількох гетерогенних середовищ

B загальнопроектну обчислювальну систему реалізації спільних інвестиційних проектів i прагнення вийти за межі лише одного підприємства залізничного транспорту, підключившись до мережі Інтернет, обумовлюють виникнення нового рівня складності.

Для подолання зазначених тенденцій перспективним $\epsilon$ створення нових поколінь інформаційних технологій і систем інформаційних технологій, а також систем, збудованих на основі концепцій адаптивного управління і самоорганізації. Розробляються самоврядні обчислювальні системи, які повинні в майбутньому самостійно організовувати своє функціонування 3 урахуванням встановлених вимог. Говорячи про властивості майбутніх адаптивних i самоорганізованих систем, необхідно, в першу чергу, виділити наступні властивості: проактивність; переконфігурації (самоконфігурування); самовдосконалення і оптимізація; самозбереження; суспільна поведінка; комунікабельність та ін.

В сучасних умовах провідні виробники комп'ютерних технологій i систем усвідомлюють необхідність i важливість проблем створення та впровадження концепції проактивного управління в інформаційну сферу. Інформаційні технології XXI століття вже отримали визначення «природні», «органічні» (Organic IT). Даною термінологією аналітики компанії «Forrester Research» (США) [9] наголошують на необхідності більш органічного, природного, безпосереднього використання інформаційних технологій в інтересах бізнес-додатків. Отже проактивне управління необхідно вважати основою забезпечення ефективності реалізації спільних інвестиційних проектів за участю підприємств залізничного транспорту.

Зважаючи на сучасні умови реалізації спільних інвестиційних проектів і теоретико-методологічні напрацювання у напрямі формування базису для їх результативного впровадження, запропоновано застосування на підприємствах залізничного транспорту моделі проактивного управління реалізацією спільних інвестиційних проектів за їх участю (рис. 2). Ключовими принципами побудови технологій і систем проактивного управління реалізацією спільних інвестиційних проектів підприємствами залізничного транспорту слід вважати: дуальне управління; зворотній зв'язок; стратегічна спрямованість; інноваційність; альтернативність рішення; оперативне кооперування планів; наукова обгрунтованість; системність; адаптивність; цифровізація.

Підводячи підсумок, можна відзначити, що кожний із вище запропонованих заходів, спрямованих на зниження ймовірності виникнення ризиків несприятливого відбору і негативної дії з боку бізнес-партнера, по-своєму $\epsilon$ ефективним і призводить до підвищення прозорості інформаційних потоків під час реалізації підприємствами залізничного транспорту спільного інвестиційного проекту. Таким чином, при грамотному i повному виконанні зазначених заходів, можна знизити асиметрію інформації між суб'єктами інвестиційної діяльності. Надалі дані концептуальні надбання доцільно використовувати для забезпечення збалансованого розвитку підприємств залізничного транспорту. Крім того, не слід забувати за виняткову роль державних регулюючих заходів, які можуть істотно поліпшити ситуацію на ринку транспортно-логістичних послуг в умовах асиметрії інформації. 


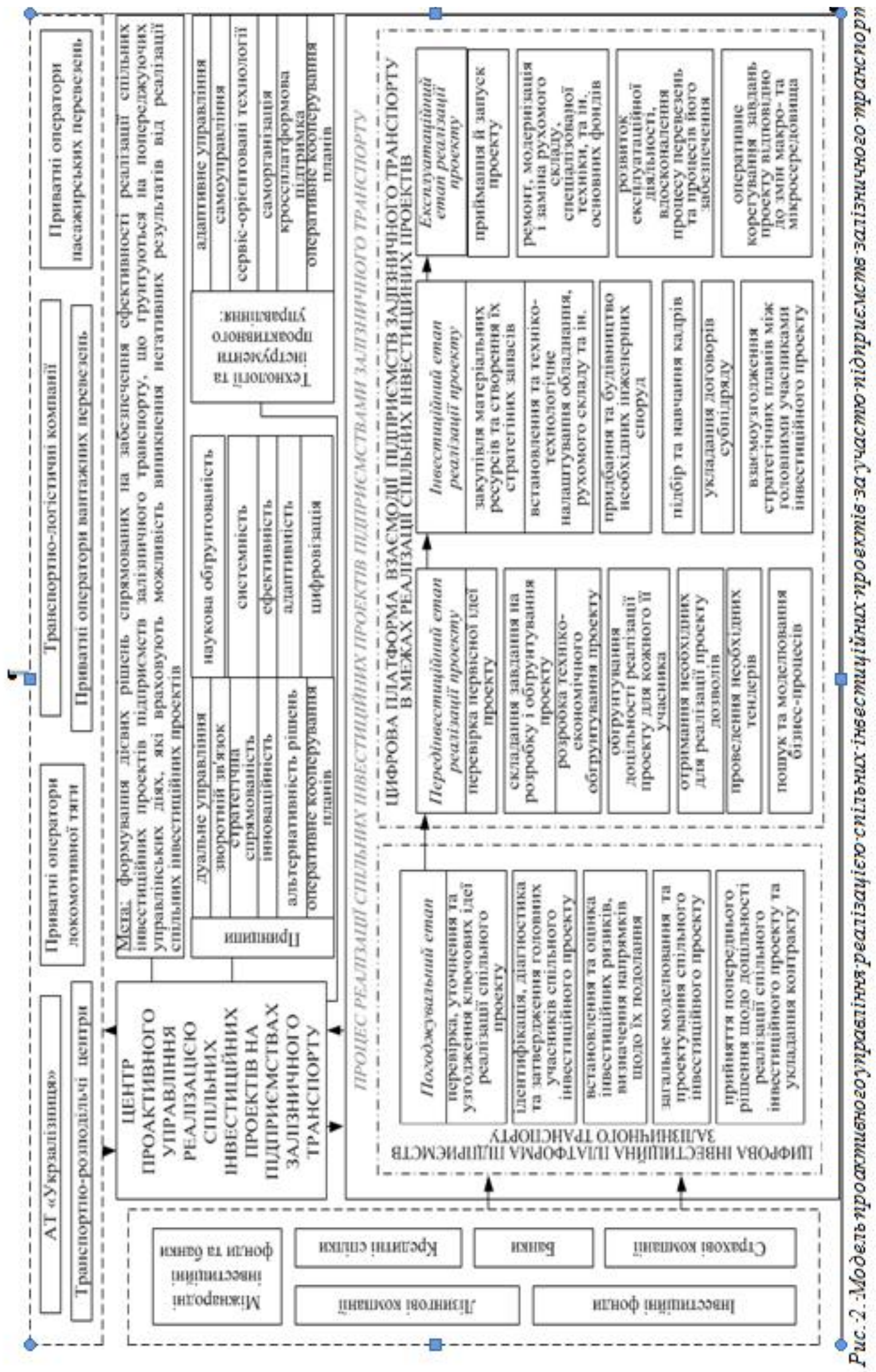


Висновки. Протягом останніх років у світовій економічній літературі істотно зросла кількість досліджень, що стосуються проблем асиметрії інформації в сфері інвестиційної діяльності. Однак питанню використання концепції проактивного управління, як ключового елементу зниження проблем асиметрії інформації та подолання інших ризиків під час управління реалізацією спільними інвестиційними проектами підприємств залізничного транспорту в умовах цифровізації, не приділялась необхідна увага.

Проведене дослідження фундаментальних наукових здобутків в сфері асиметрії інформації, ризик менеджменту, а також управління інвестиційною діяльністю в системі управління підприємствами залізничного транспорту підтверджує необхідність використання положень проактивного управління, а також введення і подальшого вдосконалення сучасних цифрових технологій для зниження асиметрії інформації між суб'єктами інвестиційної діяльності під час реалізації спільного інвестиційного проекту підприємствами залізничного транспорту. Загалом значимість даного наукового дослідження полягає в розробці моделі управління реалізацією спільних інвестиційних проектів підприємствами залізничного транспорту через призму проактивного управління, що має в основі технології цифровізації. Це в цілому забезпечить нове розуміння вирішення проблем забезпечення ефективності реалізації спільних інвестиційних проектів шляхом формування та реалізації попереджуючих управлінських діях, які враховують можливість виникнення негативних результатів від реалізації спільних інвестиційних проектів.

\section{СПИСОК ЛІТЕРАТУРИ}

1. Алешина И. А., Геращенкова T. М. Эффективный механизм реализации проектов развития транспортной инфраструктуры региона. Известия Тульского государственного университета. Экономические и юридические науки. 2016. №5. С.12-20.

2. Дикань В. Л., Островерх Г. €. Удосконалення механізмів державного управління розвитком залізничної галузі України у євроінтеграційному векторі. Вісник економіки транспорту i промисловості. 2018. №62. С. 11-19.

3. Дикань В.Л., Соломніков I.B. Інжиніринго-маркетинговий центр інноваційних технологій як основа активізації інноваційно-інвестиційного потенціалу підприємств залізничного транспорту. Вісник економіки транспорту і промисловості. 2017. Вип. 57. С. 9-20.

4. Єлагін Ю. В., Глущенко Ю. В., Цапко Л. В. Стан і оновлення рухомого складу в умовах реформування Укрзалізниці. Вісник економіки транспорту і промисловості. 2018. № 64. C. 209-216.

5. Корінь М.В., Кондратюк М.В., Обруч Г.В. Інвестиційне забезпечення розвитку залізничного транспорту України. Вісник економіки транспорту і промисловості. 2018. № 62. C. 249-259.

6. Полякова О. М., Шраменко O.В. Сучасні тенденції розвитку транспортно-логістичної інфраструктури в Україні i світі. Вісник економіки транспорту і промисловості. 2017. № 58. C. 126-134.

7. Овчиннікова В.О., Торопова B.I. Розвиток підприємств залізничного транспорту України в умовах цифровізації. Вісник економіки транспорту і промисловості. 2019. № 68. C. 175-181.

8. Покусаев О. Н., Климов А. А., Куприяновский В. П., Морхат П. М., Намиот Д. Е. Цифровая железная дорога Европы - от ERTMS до искусственного интеллекта. International Journal of Open Information Technologies. 2019. Vol. 7. C. 90-119. 
9. Токмакова

Чередниченко О.Ю., Войтов I.M., Паламарчук Я.С. Цифрова трансформація залізничного транспорту як фактор його інноваційного розвитку. Вісник економіки транспорту і промисловості. 2019. № 68. C. $125-134$

10. Шульмейстер В., Пилипчук Я. Чиє майбутне в залізничного транспорту України? Київ, 2018. 84с.

11. Антипина О. Н. Асимметрия информации. Вестник Московского университета. Сер.6. «Экономика». 2003. № 2. С. 110-125.

12. Канеман Д., Словик П., Тверски А. Принятие решений в неопределенности: Правила и предубеждения. $\mathrm{X} . \quad$ : Издательство Институт прикладной психологии «Гуманитарный Центр», 2005. 632 с.

13. Криничанский К.

B. Принятие решений в теории фирмы и теории организации// Электронный журнал «Рацио». 2013. Спец. выпуск. С. $24-42$.

URL:

http://www.kantiana.ru/upload/iblock/991/rat io.ru_2013_additional.pdf.

14. Шульц Д.Н. Подходы к измерению асимметрии информации. Международный научный журнал «Инновационная наука». 2016. №12-1. C.206-208.

15. Akerlof G., Kranton R. Economics and Identity. Quarterly Journal of Economics, 2000. №115 (3). P. 715-53.

16. Зінченко О.А., Даріюш П., Зінченко Д.С. Інформаційна економіка: концепція, сутність та розвиток. Економічний вісник НТУУ «КПІ», 2019. №16. C.3-13.

17. Мороз B.M., Мороз C.A. Ризик-менеджмент : навч. посібн. Х. : НТУ «ХПІ», 2018. 140 c.

18. Кутергина Г.В, Модорский А.В. Анализ эффективности систем управления финансовыми рисками коммерческой организации. Аудит и финансовый анализ. 2010. № 3. С. 149-162.
19. Кашуба В.М. Рискменеджмент как система управления финансовыми рисками компании. ЭТАП: «экономическая теория, анализ, практика». 2012. № 2. С. 68-83.

\section{REFERENCES}

1. Aleshina I.A, Gerashchenkova T.M. (2016) Éffektyvnyy mekhanyzm realyzatsyy proektov razvytyya transportnoy ynfrastruktury rehyona [Effective mechanism of realization of projects of development of transport infrastructure of the region]. News of Tula State University. Economic and Legal Sciences. №5. P.12-20.

2. Dykan V.L., Ostroverkh G.E. (2018) Udoskonalennya mekhanizmiv derzhavnoho upravlinnya rozvytkom zaliznychnoyi haluzi Ukrayiny $u$ yevrointehratsiynomu vektori [Improvement of the mechanisms of state management of the development of the Ukrainian railway industry in the European integration vector]. Bulletin of Economics of Transport and Industry. №62. P. 11-19.

3. Dykan V.L., Solomnikov I.V. (2017) nzhynirynho-marketynhovyy tsentr innovatsiynykh tekhnolohiy yak osnova aktyvizatsiyi innovatsiyno-investytsiynoho potentsialu pidpryyemstv zaliznychnoho transportu [Engineering and marketing center of innovative technologies as a basis for activation of innovation and investment potential of railway enterprises]. Bulletin of Economics of Transport and Industry. Vol. 57. P. 9-20.

4. Yelagin Y.V., Glushchenko Y.V., Tsapko L.V. (2018) Stan i onovlennya rukhomoho skladu $v$ umovakh reformuvannya Ukrzaliznytsi. [Condition and rolling stock renewal under conditions of Ukrzaliznytsya reform]. Bulletin of Economics of Transport and Industry. № 64. P. 209-216.

5. Korin M.V., Kondratyuk M.V., Obruch G.V. (2018) Investytsiyne zabezpechennya rozvytku zaliznychnoho transportu Ukrayiny [Investment support for 
the development of railway transport in Ukraine]. Bulletin of Economics of Transport and Industry. No. 62. P. 249-259.

6. Polyakova O.M., Shramenko O.V. (2017) Suchasni tendentsiyi rozvytku transportno-lohistychnoyi infrastruktury $\mathrm{v}$ Ukrayini i sviti [Current trends in the development of transport and logistics infrastructure in Ukraine and in the world]. Bulletin of Economics of Transport and Industry. No. 58, P. 126-134.

7. Ovchynnikova V.A., Toropova V.I. Rozvytok pidpryyemstv zaliznychnoho transportu Ukrayiny $\mathrm{v}$ umovakh tsyfrovizatsiyi [Development of railway enterprises of Ukraine in the conditions of digitalization]. Bulletin of Economics of Transport and Industry.№ 68. P. 175-181.

8. Pokusayev O.N., Klimov A.A., Kupriyanovsky V.P., Morkhat P.M., Namiot D.E. (2019) Tsyfrovaya zheleznaya doroha Evropy - ot ERTMS do yskusstvennoho yntellekta [Digital railway of Europe - from ERTMS to artificial intelligence]. International Journal of Open Information Technologies . Vol. 7. PP. 90-119.

9. Tokmakova I.V., Cherednichenko O.J., Voitov I.M., Palamarchuk Y.S. (2019) Tsyfrova transformatsiya zaliznychnoho transportu yak faktor yoho innovatsiynoho rozvytku [Digital transformation of railway transport as a factor of its innovative development]. Bulletin of Economics of Transport and Industry. № 68. P. 125-134.

10. Shulmeister V., Pylypchuk Y. (2018) Chy ye maybutnye v zaliznychnoho transportu Ukrayiny? [Whose future is in Ukrainian rail transport?] Kyiv. 84 p.

11. Antipina O.N. (2003) Asimmetriya informatsii [Asymmetry of information]. Bulletin of the Moscow University. Aug.6. "Economics". No. 2. P. 110-125.

12. Kahneman D., Slovik P., Tverski A. (2005) Prinyatiye resheniy V neopredelennosti: Pravila i predubezhdeniya [Decision making in uncertainty: Rules and preconceptions]. Kh.: Publishing House of the Institute of Applied Psychology "Humanitarian Center", 632 p.

13. Krynichansky K.V. (2013) Prinyatiye resheniy $\mathrm{v}$ teorii firmy i teorii organizatsii [Decision Making in Company Theory and Organization Theory] Electronic journal "Ratsio". Special. issue. P. 24-42. URL:

http://www.kantiana.ru/upload/iblock/991/rat io.ru_2013_additional.pdf.

14. Schultz D.N. (2016) Podkhody k izmereniyu asimmetrii informatsii [Approaches to measuring information asymmetry]. International scientific journal “Innovative Science”. №12-1. P.206-208.

15. Akerlof G., Kranton R. (2000) Economics and Identity [Economics and Identity]. Quarterly Journal of Economics. №115 (3). P. 715-53.

16. Zinchenko O., Dariusz P., Zinchenko D. (2019) Informatsiyna ekonomika: kontseptsiya, sutnist' ta rozvytok [Information economy: concept, essence and development]. Economic Bulletin of NTUU “KPI”. №16. P.3-13.

17. Moroz V.M., Moroz S.A. (2018) Ryzyk-menedzhment : navch. posibn. [Risk Management: Educ. Manual] H.: NTU "KPI". 140 p.

18. Kutergina G.V., Modorsky A.V. (2010) Analyz éffektyvnosty system upravlenyya fynansovymy ryskamy kommercheskoy orhanyzatsyy [Analysis of efficiency of financial risk management systems of a commercial organization]. Audit and financial analysis. № 3. P. 149-162.

19. Kashuba V.M. (2012) Ryskmenedzhment kak systema upravlenyya fynansovymy ryskamy kompanyy [Risk management as a system of financial risk management of the company]. STAGE: "economic theory, analysis, practice". № 2 . P. 68-83. 